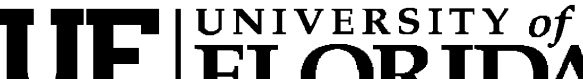 FLORIDA \\ IFAS Extension
}

\section{Dwarfing and Freeze Hardiness Potential of Trifoliate Orange Rootstocks ${ }^{1}$}

\section{James J. Ferguson and Jose Chaparro ${ }^{2}$}

Commercial nurseries, growers, and homeowners who produce or grow citrus trees north of Gainesville should use a freeze hardy rootstock such as trifoliate orange (Poncirus trifoliata) or one of its hybrids. Trifoliate orange is in the same taxonomic group as other types of citrus like oranges (Citrus sinensis) and grapefruit (Citrus paradisi) but it is in a different genus. It is not really an "orange" in the common sense of the word.

Other commercial citrus rootstocks also have trifoliate orange parentage. Carrizo citrange is a hybrid of Washington navel and trifoliate orange. Swingle citrumelo is a hybrid of Duncan grapefruit and trifoliate orange. The leaves of trifoliate orange and of other rootstocks with trifoliate orange parentage have "trifoliate" or compound leaves divided into three leaflets or sections (Fig. 1).

Trifoliate orange trees produces seedy, round, golf-ball size fruit (Fig. 2) that are not edible. These trees have the potential to survive low temperatures and, when used as a rootstock, can impart some freeze hardiness to scion trees grafted onto it. Trifoliate orange is also deciduous, shedding its leaves in the winter. Most citrus varieties propagated on trifoliate orange rootstock are also reduced in size, especially when Flying Dragon, a selection of trifoliate orange, is used. While Flying Dragon has shown some promise as a freeze hardy and dwarfing rootstock, questions often arise about its rootstock genetics, rootstock/scion interactions, and cultural practices that can affect tree size. Accordingly, the purpose of this fact sheet is to discuss these issues as they relate to trifoliate orange rootstocks, especially Flying Dragon.

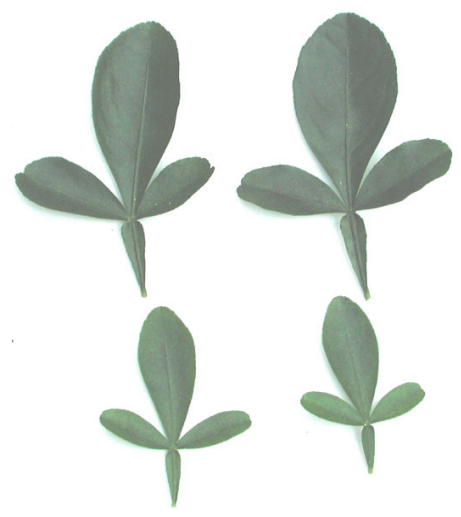

Figure 1. Compound leaves of trifoliate orange and related rootstocks are divided into three leaflets.

1. This document is HS982, one of a series of the Horticultural Sciences Department, Florida Cooperative Extension Service, Institute of Food and Agricultural Sciences, University of Florida. Publication date: October 2004. Please visit the EDIS Web site at http://edis.ifas.ufl.edu.

2. James J. Ferguson, professor, Jose Chaparro, assistant professor, Horticultural Sciences Department, Cooperative Extension Service, Institute of Food and Agricultural Sciences, University of Florida, Gainesville, 32611.

The Institute of Food and Agricultural Sciences (IFAS) is an Equal Opportunity Institution authorized to provide research, educational information and other services only to individuals and institutions that function with non-discrimination with respect to race, creed, color, religion, age, disability, sex, sexual orientation, marital status, national origin, political opinions or affiliations. U.S. Department of Agriculture, Cooperative Extension Service, University of Florida, IFAS, Florida A. \& M. University Cooperative Extension Program, and Boards of County Commissioners Cooperating. Larry Arrington, Dean 


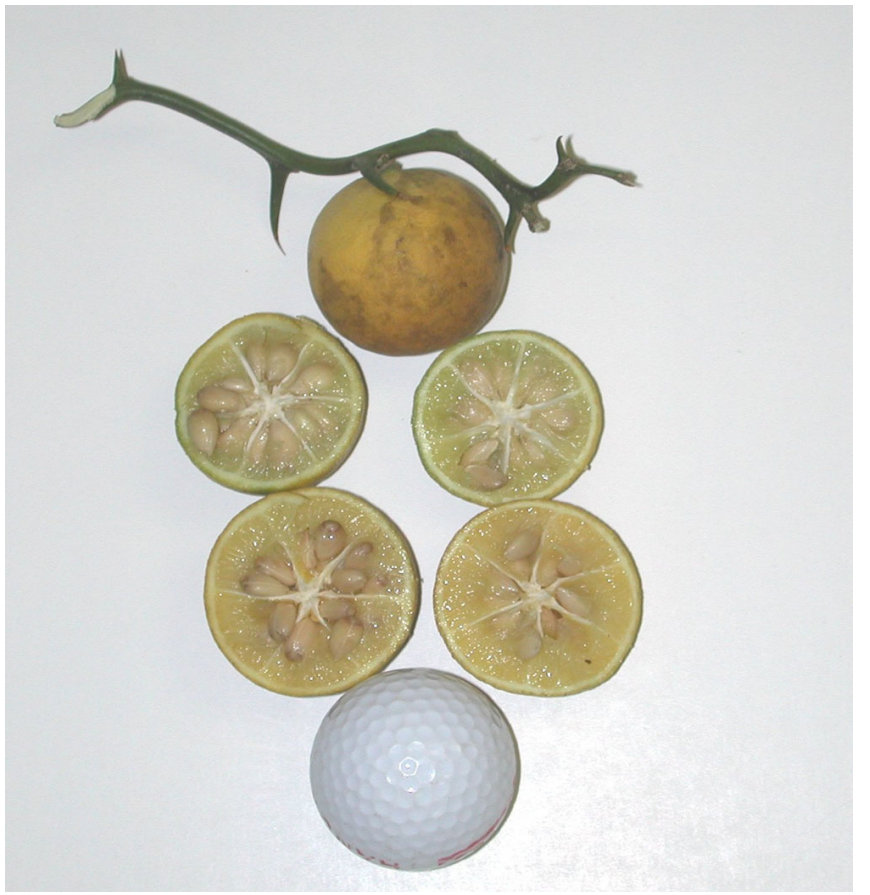

Figure 2. Seedy fruit and stem of a trifoliate orange selection called Flying Dragon. Find the dragons in the twig.

\section{How Does Dwarfing Occur?}

For commercial growers and homeowners, a dwarf tree is simply one defined by convention as being about 5 to 6 feet tall at maturity. This particular tree height is somewhat arbitrary and is based mostly on comparison to a standard-sized tree which is usually about 15 to 20 feet tall at maturity. In other words, a common grapefruit or sweet orange tree on "standard" or non-dwarfing commercial rootstocks will reach a 15 to 20 -foot height at maturity, while a tree on Flying Dragon may grow to only "dwarf" size.

Commercial citrus growers have been interested in dwarfing rootstocks for citrus because small tree size allows a higher tree number or density per acre, fewer if any hedging and topping (pruning) costs, and easier fruit harvesting on smaller trees. A number of factors can influence tree size, but for most commercial citrus cultivars, research has shown that tree size can be greatly modified by selecting an appropriate rootstock. For example, trifoliate orange rootstock selections have been generally divided into two groups based on flower size. Trees on small-flowered trifoliate orange selections like Rubidoux are typically 15 to $20 \%$ smaller than trees on large-flowered selections like Pomeroy. In
California, where dwarfing citrus rootstocks have been widely used, 8-to-12-year-old navel and Valencia oranges, Minneola tangelos, and Dancy tangerines on Rubidoux trifoliate orange rootstock at different sites ranged from 10 to 14 feet tall. Comparable trees on Pomeroy trifoliate rootstock were predicted to be $15-20 \%$ taller, about 12 to 17 feet.

Using an interstock between the rootstock and the scion, done more successfully with apples than with citrus, can also reduce tree size. However, in some cases, interstock effects on tree size can be counteracted by rootstock effects. For example, a Hamlin sweet orange scion on a Flying Dragon interstock on a vigorous Volkamer lemon rootstock was 30\% larger than Hamlin with a Flying Dragon interstock on a less vigorous rootstock, Carrizo citrange.

Environmental factors like soil type, mild drought, soil salinity or alkalinity, marginal growing sites, or climate can affect tree size. Trees on trifoliate orange rootstock are often smaller-sized when grown in deep, sandy soils even with irrigation. On better soils, these trees grow slowly but reach standard size. In Australia, deliberately infecting trees with the citrus exocortis viroid, a virus-like pathogen, has dwarfed trees but this procedure has not been widely adapted on a commercial scale because of potential risks and uncertainties related to using this pathogen. For example, in Florida, trees deliberately infected with citrus exocortis sustained greater freeze damage than comparable trees that were not infected.

Growth hormones like auxins and cytokinins have been used to reduce tree size and have decreased internode length (the gap between successive points of attachment of leaves on a stem) and increased lateral shoot development. Other cultural practices like growing otherwise standard rootstock/scion combinations in small pots will result in a dwarfed tree, but if such trees were transplanted into the home landscape or a commercial citrus grove, they could grow into standard size trees. To cite another example, bonsai, usually ranging from 2 inches to about 3 fee tall, are not genetically dwarfed plants but are standard size plants kept small by pruning 
branches and roots, repotting, and pinching off new growth. Small-leafed ornamentals like camellias are commonly used for bonsai but Flying Dragon rootstock, with its downcurved thorns and sinuous or winding growth habit, might also make an interesting bonsai specimen.

\section{Characteristics of Trifoliate Orange Rootstock}

Trifoliate orange is suitable for use in cool climates where maximum freeze hardiness can be developed. Freeze hardy rootstocks, like trifoliate orange, acquire freeze hardiness at $70^{\circ} \mathrm{F}$ day temperatures $/ 50^{\circ} \mathrm{F}$ night temperatures whereas the less freeze hardy rootstocks do not acquire freeze hardiness until $50^{\circ} \mathrm{F}$ day $/ 30^{\circ} \mathrm{F}$ night temperatures occur. During the fall and winter, cooler temperatures occur more frequently in northern than in central or southern Florida, but even in north Florida, unseasonably warm temperatures higher than $70^{\circ} \mathrm{F}$ day $/ 50^{\circ} \mathrm{F}$ night cited above can reduce the freeze hardiness of trifoliate orange rootstocks. Trifoliate orange therefore may not be a consistently freeze hardy rootstock.

Given acclimating temperatures as unbudded seedlings, trifoliate orange rootstock is much more freeze hardy than most commercial citrus rootstock and scion cultivars. Trees on trifoliate orange rootstock also tend to be more freeze hardy than trees on other commercial rootstocks. Fully acclimated two-year old trifoliate orange seedlings survived $3^{\circ} \mathrm{F}$ temperatures in Georgia and Owari satsumas on trifoliate orange rootstock survived $14^{\circ} \mathrm{F}$ temperatures in Louisiana.

Interestingly, trees on Flying Dragon rootstock have not been shown to be more freeze hardy than trees on other trifoliate orange types. In one study examining the effects of rootstocks on freeze hardiness of navel oranges in California with minimum temperatures of $18^{\circ} \mathrm{F}$ and a long preceding period of freeze-hardening temperatures, trees on Flying Dragon were similar to trees on Pomeroy and Rubidoux trifoliate orange rootstocks. Note also that when severe freeze damage does occur to trees on trifoliate orange rootstock, they recover more slowly than trees on more freeze sensitive but more vigorous rootstocks like rough lemon.
Trifoliate orange is a satisfactory rootstock for most sweet orange cultivars, especially navels but fruit size for grapefruit scions on trifoliate orange rootstocks may be relatively small. When trifoliate orange is used as a rootstock for mandarins and mandarin hybrids, bud union incompatibility has been reported. Trees budded on trifoliate orange produce excellent fruit with high soluble solids, good juice color and a smooth thin peel. Fruit also holds well on the tree. However, fruit, especially for the fresh market, can be small because of heavy fruit set.

When used as a rootstock, trifoliate orange can produce a standard tree size, about 15 feet tall, on clay and loamy soils and on shallow soils but does not develop a deep or widely ranging root system and consequently is not drought hardy. On deep, sandy Ridge soils, trees on trifoliate orange do not grow rapidly, making it a good candidate for close plantings with irrigation. It is poorly adapted to saline or calcareous conditions but is useful under wet conditions because of resistance to Phytophthora foot rot. Tree stunting and rootstock bark scaling associated with citrus exocortis and citrus blight, a decline of mature trees, are perhaps the most serious diseases affecting this rootstock. Some trifoliate orange selections are tolerant to citrus nematode but all selections are susceptible to burrowing nematode. Performance of trees on Flying Dragon rootstock may be similar to the above with tree size variability discussed in following sections.

\section{Polyembryony and Nucellar Seedlings}

The genetics of trifoliate orange rootstocks are complex and may explain differences in the size of trees grafted onto these rootstocks, especially Flying Dragon. Citrus and related species are unique because of the frequent occurrence of polyembryony (one seed producing a number of embryos or seedlings) and nucellar embryony (seedlings genetically identical to the mother plant as opposed to zygotic seedlings which inherit genetic characteristics from both parent plants). Rootstocks that are strongly nucellar produce a high percentage of nucellar seedlings whereas weakly nucellar rootstocks can produce a significant percentage of both nucellar and zygotic seedlings. In one report, using seed from 
Flying Dragon trees grown in four different locations, the frequency of zygotic seedlings ranged from 0 to $75 \%$. Researchers also found that the percentage of Flying Dragon nucellar and zygotic seedlings fluctuated greatly from year to year on the same tree.

When producing citrus nursery trees, nurserymen select rootstock seedlings for uniformity and discard any that are off-types that vary in characteristics like internode length, leaf size, shape and color, growth rate, foliage density, and branching. Such non-uniform or off-type seedlings probably developed from zygotic embryos (Figs. 3, 4, 5 and 6). If these off-types were used as rootstocks and grafted with a scion cultivar like Valencia orange, the resulting trees may not produce fruit of as uniform a quantity and quality as that same fruiting cultivar grafted onto comparable nucellar rootstock seedlings. Rootstock disease susceptibility could also vary. Although off-type rootstock seedlings should generally be avoided, they may have potentially interesting characteristics.

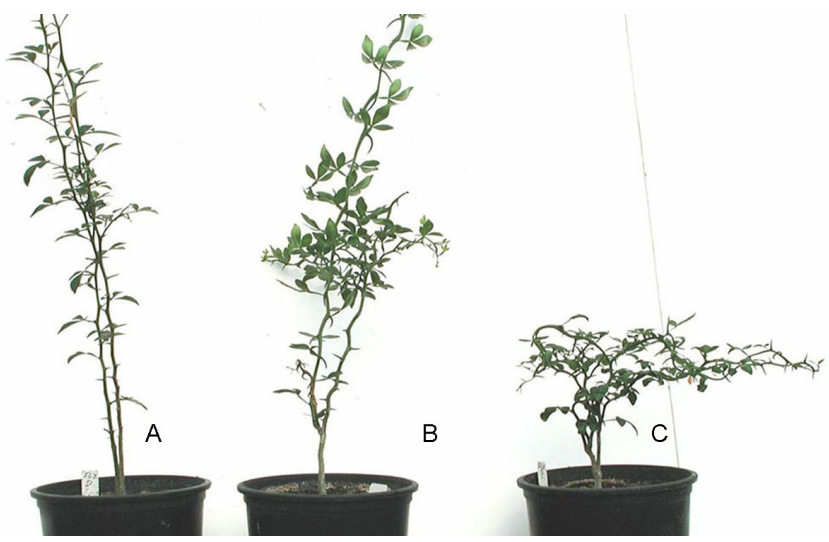

Figure 3. Flying Dragon seedlings from the same source. Note variability in stem height and relative straightness of stems and thorns.

The important point is that the occurrence of polyembryony and nucellar seedlings varies in trifoliate orange rootstocks. This variation can explain why Flying Dragon as a rootstock seedling and as a rootstock/scion combination can include both nucellar and zygotic seedlings and can produce both trees of standard size and trees of varying size, including dwarf trees. Environmental factors like soil conditions can also affect growth, tree size, and yield. Selected research on tree size, tree density per acre and yield of different scion cultivars on Flying Dragon rootstock is presented in Table 1.

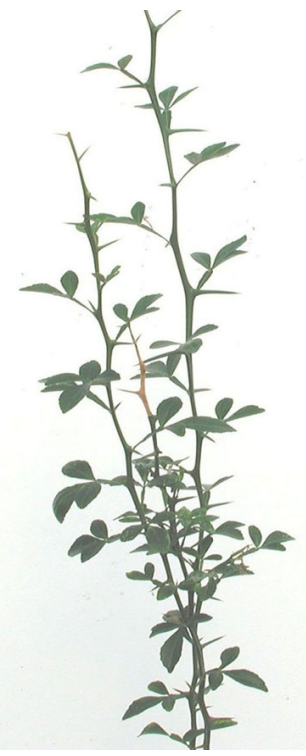

Figure 4. A closer image of plant A in Fig. 3.

Although the specific mechanism for dwarfing is not clearly understood, when used as both a rootstock and as an interstock, it has been suggested that Flying Dragon tissue may bind or inactivate translocation of a growth regulator produced by its roots. Further research may focus on identifying and transferring dwarfing factors to other rootstocks with more desirable traits.

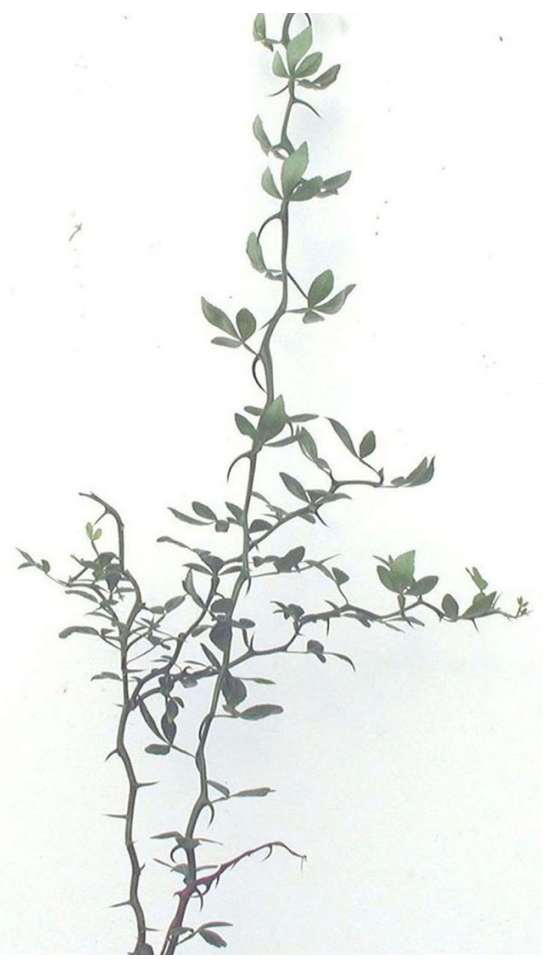

Figure 5. A closer image of plant B in Fig. 3. 


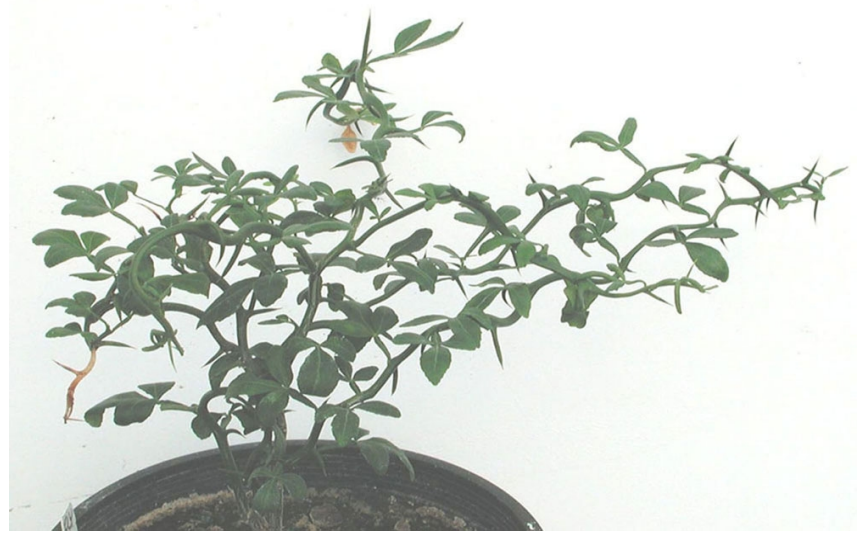

Figure 6. A closer image of plant $C$ in Fig. 3. This appears to be a true-to-type genetic dwarf while the other plants may be off-types. 
Table 1. Selected research on growth and yield of scions on Flying Dragon rootstock (FD).

\begin{tabular}{|c|c|c|}
\hline Experiment & Results & $\begin{array}{c}\text { Country } \\
\text { (Publication date) }\end{array}$ \\
\hline $\begin{array}{l}\text { Mandarins and grapefruit on sour orange, Rangpur } \\
\text { lime, and other rootstocks with a FD interstock } \\
\text { planted deeply, assumably to induce interstock } \\
\text { rooting to control tree size after early vigorous } \\
\text { growth with the sour orange rootstock }\end{array}$ & $\begin{array}{l}\text { 6-year-old trees trees with a FD interstock } \\
\text { were } 30-50 \% \text { smaller. Trees planted at a } 3 \text { x } \\
16 \mathrm{ft} . \text { spacing had a } 1.6 \mathrm{ft}^{3} \text { tree volume and } \\
67 \mathrm{lbs} / \text { tree yield. }\end{array}$ & Israel (1992) \\
\hline 8 citrus cultivars on FD & $\begin{array}{l}\text { At } 5 \text { years old, trees could be planted at } 333 \text { - } \\
583 \text { trees/acre, } 5 X \text { more than a conventional } \\
\text { orchard at } 1.8 X \text { greater costs and } 5.2 \mathrm{X} \\
\text { greater production. }\end{array}$ & $\begin{array}{l}\text { New Caledonia } \\
\text { (1999) (South } \\
\text { Pacific off } \\
\text { Australia) }\end{array}$ \\
\hline Lemons on FD & $\begin{array}{l}\text { 12-year-old trees had } 1 / 3 \text { the canopy volume } \\
\text { of trees on sour orange rootstock with fruit } \\
\text { yield of } 441 \mathrm{lbs} / \text { tree. Trees were } 11.5 \mathrm{ft} \text {. tall. }\end{array}$ & Argentina (1996) \\
\hline Sweet orange on FD & $\begin{array}{l}\text { 9-year-old trees were } 6 \text { feet tall and @ } 4.5 \mathrm{ft} \\
\text { in width. }\end{array}$ & California (1982) \\
\hline Pineapple sweet orange and Ruby grapefruit & $\begin{array}{l}\text { 5-year old pineapple sweet orange and Ruby } \\
\text { grapefruit trees }(15 \times 20) \text { on Flying Dragon } \\
\text { rootstock were } 3.2 \text { and } 4.0 \text { feet tall, } \\
\text { respectively, compared with the same scions } \\
\text { on Carrizo citrange which were } 6.6 \text { and } 6.0 \\
\text { feet tall, respectively. }\end{array}$ & Florida (1980) \\
\hline Valencia on FD & $\begin{array}{l}\text { 4-year-old trees (averaging } 4 \text { feet tall and } \\
\text { three feet wide) averaged } 71 \text { fruit per tree } \\
\text { compared with trees of the same age on a } \\
\text { vigorous rootstock, rough lemon ( } 10 \text { feet tall } \\
\text { and } 7 \text { feet wide) averaging } 541 \text { fruit per tree. }\end{array}$ & California (1986) \\
\hline Valencia on FD & 5 -year-old trees ( 6 feet tall and 6 feet wide) & California (1979) \\
\hline
\end{tabular}

